\title{
PARP1 Gene Product
}

National Cancer Institute

\section{Source}

National Cancer Institute. PARP1 Gene Product. NCI Thesaurus. Code C104101.

A protein encoded by the PARP1 gene. 